\title{
THE TWO “MULTIS” AND THE MULTILITERACIES PEDAGOGY: "SHAKING HANDS" IN THE BRAZILIAN ENGLISH PUBLIC EDUCATION FOR TEENS
}

\author{
Open your books to page 9. Now, close your books, and you may go home \\ Reinildes Dias ${ }^{{ }^{*}}$ \\ ${ }^{1}$ Universidade Federal de Minas Ferais, Belo Horizonte, MG, Brasil \\ Ana Emília Fajardo Turbin ${ }^{2 *}$ \\ Universidade de Brasília, Brasília, DF, Brasil
}

\begin{abstract}
${ }^{1}$ English school textbooks have a long tradition in the Brazilian public sector of education. Most often they are the only pedagogical resources in an English classroom. English public textbooks are submitted to a National Program for evaluation and this educational policy has had positive impacts on these materials. This article analyzes one of the units of a textbook series for teens that was approved in 2020. Our analysis focuses on the two "multis", the multiliteracies pedagogy and the active role today's learners play in learning. We also highlight some alternatives for improvements and give some suggestions for English teachers. The documentary research method within the qualitative paradigm supports our analysis. Our results show that the unit follows the principles of the two "multis" and the cycle of knowledge processes although its pedagogical design can be improved. Our analysis also reviews that much has yet to be done if we consider the responsibility students must assume when learning.

Keywords: English school textbooks; multiliteracies; pedagogical design; public education for teens; Brazilian context.
\end{abstract}

\footnotetext{
'Associate Professor at UFMG . Holds a Ph.D. in Educational Technology from Canada's Concordia University in Montreal. As a member of the post-graduate program, POSLIN - CAPES 7 at FALE, UFMG, she carries out studies related to language and digital technologies. She supervises academic work that is mainly oriented to teacher education in the context of Brazilian public / private schools. Her goal is to empower English teachers to respond to literacy pedagogy in their teaching. She is often invited to give workshops, lectures and plenaries in conferences all over Brazil. She was a consultant to the Department of Education of the State of Minas Gerais for a long time. reinildes@gmail.com Orcid: https://orcid.org/0000-0001-6140-463X.

${ }^{* *}$ Associate Professor at UnB. Holds a Ph.D. in Education from the University of São Paulo (USP). She is an associate professor at the University of Brasilia (UnB) and a member at the Graduate program of Applied Linguistics (PGLA). She was awarded with a PRODOC CAPES scholarship for post-doctoral research in the University of Tocantins and later concluded post-doctoral studies in the area of educational technology at UFMG. Her themes of research are: teaching and learning an additional language (English), discourse analysis, teacher education, and bilingual education. She has held positions as coordinator in various programs, PIBID and Pedagogic Residence (CAPES). Presently, she does research on Multiliteracies, Multimodality and bilingual education. As a member of the UnB Idiomas Extension Program, she coordinates and teaches courses on bilingualism. anemiliaturbin@gmail.com Orcid: https://orcid.org/0000-0002-7239-5668.
} 


\section{Introduction}

Throughout the years, textbooks have always had an essential place in English classrooms since it has been, not only a dictator of the contents that should be taught, but a good ally friend of the English teacher as well. Teachers were expected to simply transmit what was listed in their table of contents in the hope their students would passively learn based on what they exposed in usually long lectures of their own. Learning activities for the active participation of students were few - let alone experiences that would require the creative transformation of knowledge to show what they had learned. Didactive literacy pedagogy as recently named by Kalantzis and Cope (2012, p. 61) was the dominant approach in English classes. Emphasis was then on repetition, memorization, and grammar rules. However, the contemporary student does not necessarily conjugate verbs or repeat the exact words listed, in a rote, mechanical way. The new students are encouraged to be active agents of their own learning and textbooks must encompass multimodal texts like the ones they read outside of school together with challenging activities, themes of social relevance that give them the opportunity of developing smart communication and critical thinking. Above all, they are digital citizens that can communicate online with youngsters around the world on any subject that interests them.

In the Brazilian context, English teaching at public schools is mandatory from the sixth grade onward. Some public schools, however, offer English as an additional language at the lower grades as, for example, through the Bilingual Project in Londrina in Paraná, one of the most innovative programs for public school young children in Brazil (Tonelli \& Furlan, 2021). In most cases, private schools offer English earlier than the $6^{\text {th }}$ grade. For the public sector, there exists the National Program of School Textbooks (whose acronym is PNLD in Portuguese meaning Programa Nacional do Material e Livro Didático) (Brasil, 2020). A committee appointed by the Brazilian Ministry of Education - usually formed by University professors and public English teachers - evaluates the textbooks submitted to the program and issues a guide on the ones that are approved. It is an ample program and teachers of all subjects, including English, have the chance to choose the series of textbooks that are more appropriate to their contexts. The PNLD authors and publishing houses have to strictly follow the Brazilian Common National Curriculum Base (BNCC, acronym in Portuguese meaning Base Nacional Comum Curricular) that specifies a common core of ethical values, competences and abilities for the process of teaching and learning English in all Brazilian schools.

We will focus on one of the units of the school textbook series, Time to share, published by the Brazilian publishing company Saraiva in 2018. This book was approved by the 2020-PNLD and is being used by Brazilian English teen students all over the country. We will discuss aspects of theory and practice to support our analysis of one of the units of this series from three main perspectives based on The New London Group Manifesto (1996), Kalantzis \& Cope (2012), and 
Prensky, (2010). Our analysis is aimed on discussing how these three perspectives are intertwined in the textbook activities supported by the "why", "what" and the "how" of the multiliteracies pedagogy. We will also highlight the active role learners should take in the learning process. Finally, we will turn our analysis into some guidelines for English teachers who choose PNLD textbooks for their pedagogical practices. In our brief final section, we will emphasize that students' own learning is their responsibility in terms of what they do to learn.

\section{A brief review of theory and practice in a world of change}

Multiliteracies. The New London Group (known by the acronym NLG), formed by highly regarded researchers, got involved in exhaustive discussions concerning the massive changes brought to society by digital technologies, especially in language communication. They issued a manifesto with their concerns and possible alternatives for the present educational scenario. The group participants argued that "the mission of education $[\ldots]$ is

to ensure that all students benefit from learning in ways that allow them to participate fully in public, community and economic life." As such, literacy pedagogy "portrayed by traditional language-based approaches [...] restricted to formalized, monolingual, monocultural, and rulegoverned forms of language cannot account for the context of our [current] culturally and linguistically diverse and increasingly globalized society" (The NLG Manifesto, 1996, p. 60-61).

These researchers and their colleagues also argued that the concept of literacy pedagogy was unable to encompass the variety of textual layouts that include the verbal (written or oral) mode and others, such as, visual, spatial, audible/onomatopoeic sounds, typography (Kress, 2010). Therefore, literacy pedagogy has not taken into consideration the prevailing semiotic landscapes of oral/written communications of the present era. Their pioneering work stressed that a shift in literacy should be brought about with the notion of a theory of multiliteracies that could "fit in well with the view of social life and social subjects in fast-changing and culturally diverse societies" (Kalantzis \& Cope, 2012, p.13) of today's digital age. According to them, the two "multis" bring together two important conceptual dimensions: diversity and multimodality.

The first "multi" refers to how meanings vary in relation to different cultures, depending on the situation and the cultural background that implies diversity in its forms: gender identity, life experience, cultural settings, and other variables. As the authors state "[n]egotiating these language differences and their patterns or designs become a crucial aspect of literacy learning." (Kalantzis \& Cope, 2012, p. 1). The diverse conventions in a myriad of different social and cultural contexts influence the ways we communicate when we move between different social engagements - at home with family, in entertaining events with friends, in employment settings and in the oral/written interactions within the working 
community, for example. These different social roles we play require a broader view of literacy and the ways it can be achieved for meaning making and respect for others. As mentioned in the NLG Manifesto,

[a]ny successful theory of pedagogy must be based on views about how the human mind works in society [ ... ], as well as about the nature of teaching and learning." Their "assumption is that the "human mind is embodied, situated and social" meaning that "human knowledge is [...] developed not as 'general and abstract', but as embedded in social, cultural, and material contexts (The New London Group Manifesto, 1996, p. 82)

The other "multi", multimodality, is explained by Dias (2015, p. 305) as follows:

[t]he various texts from several genres start to incorporate multiple semiotic modes on the written page and on the computer screen, in the oral messages, in face-to-face conversations, and in the media such as radios, television, CD Roms, and the web." (Dias, 2015, p. 305)

According to her, this entails new identities for the contemporary texts in which there is no prevalence of the written and spoken modes to express meaning but, instead, there is an orchestration of different modes of representation through images, sounds, gestures, and the page itself or the computer screen (Kress, 2010). As such, meaning is conveyed in ways that are increasingly multimodal. Dias's (2020, p. 247) diagram summarizes what the semiotic modes are and their respective resources in Figure 1.

Figure 1 - Semiotic Modes and Resources

Semiotic modes
of meaning-making
and corresponding
$\begin{gathered}\text { Visual mode } \\ \text { language, cohesive devices, hesitations, fillers, etc. } \\ \text { Resources: images, photos, emojis, colors, shades and } \\ \text { tints, perspectives, sizes, placement on the page, etc. }\end{gathered}$
$\begin{aligned} & \text { Auditory mode } \\ & \text { Resources: sounds, soundtracks, sound effects, noises, } \\ & \text { intonation, rhythm, whistles, etc. }\end{aligned}$
$\begin{gathered}\text { Gestural mode } \\ \text { Resources: gestures, body language, posture, facial } \\ \text { expressions, etc. }\end{gathered}$
$\begin{gathered}\text { Spatial mode } \\ \text { Resources: white space, layout, frames for salience of } \\ \text { important information, etc. }\end{gathered}$
Typography mode
Resources: typefaces and sizes, bullets, quoted passages,
headings and titles, etc.


In short, the multiliteracies theory of meaning acknowledges the social, cultural and contextual changes in society and in the ways we communicate and deal with diversity due to the digital technologies of the present age. Everything is faster than it once was and subject to ongoing transformation and we all must cope with playing different roles in a variety of social spaces to which we must necessarily adjust. If we need a word to represent all these elements influenced by digital technologies, it is "multiplicity".

\section{Multiliteracies pedagogy: why, what, how}

The impact of digital technologies on language communication and diversity within different social contexts made the NLG researchers (1996) realize that the two "multis" were necessary to broaden understanding of teaching and learning to account for the escalating changes in society. Demands were ripe for a multiliteracies pedagogy to account for the social changes and the multiple modes of communication of this age. The main aim of this new pedagogy was (and still is) to overcome the limitations of traditional teaching approaches. The authors also say that cultural differences in our society impose new ways of preparing students to be "problem-solvers, broadly knowledgeable, capable of applying divergent ways of thinking [and also] innovative and creative risktakers" (Kalantzis \& Cope, 2012, p.7).

To understand the reasons "why" it is necessary to broaden our pedagogical scope to encompass multimodal communication and "the realities of increasing local diversity and global connectedness (p. 64)", the following questions are raised: "what" and "how" are students to be educated to live in this digital age?

Concerning the "what", the concept of the two "multis", multiple diversity and multimodality, is essential. Learning involves meaning-making that reflects learners' interests, cultural experiences, subjectivity, and identity. Although learning is based on different sources of information as, for example, students' previous knowledge, teacher's and colleagues' feedback; scaffolding, among others, the students themselves do assume a pivotal role in weaving these sources in the process of constructing meaning or meaning making. Their agency is key. As multimodal genres coming from diverse contexts are at the core of any type of learning, multimodality must be in scene when the "what" of the multiliteracies pedagogy is addressed.

Regarding the "how" of a multiliteracies pedagogy, a key concept is the notion of "knowledge processes" or "things you do to know" that encompasses four types of thinking in-action processes: experiencing, conceptualizing, analyzing, and applying, added to the two "multis" as well as to the digital component in the meaning-making process. The aim is to broaden students' capacity to do things to know (or to learn).

The learning activities related to these processes are not designed in a sequence and do not require "balance" because they depend on the learning situation and students' previous knowledge and expectations: some subjects may 
call for a lot of conceptual effort - others need more experiencing or analyzing. The process of applying creatively involves the creation of a transformative resource or something new as, for example, a video, a podcast or an infographic. This whole process calls for creative applications "of knowledge and understandings of the complex diversity of real-world situations" (Kalantzis \& Cope, 2012, p. 359). School textbooks that include a purposeful weaving of these knowledge processes will encourage learners to focus on things they learn to do to know or construct meaning. The multiliteracies pedagogy is a "transformative paradigm of learning" with focus on learning for the contemporary age whose aim is

to transform today's learning environments and create learning for the future - learning environments which could be more relevant to a changing world, more effective in meeting community expectations and which manage educational resources more efficiently. (Kalantzis \& Cope, 2010, p. 200)

\section{Digital students of the new age}

The question is now: who are the students of contemporary English classrooms? We ask this question that is fundamental when teaching them, writing texts and creating pedagogical resources oriented to their process of learning a(n) additional/foreign language. According to some research conducted by the Universe Online (UOL), a Brazilian section of a newspaper called Folha de Sao Paulo (Dias, 2019), young people nowadays are more realistic than their past counterparts. They are called the $\mathrm{Z}$ generation that often uses irony to criticize society abolishing the idea of perfection.

The motto of today's young people is to be original and narrate their moments in Instagram stories or post them in other social media - experiences and sufferings of any kind. YouTube brings the Z's songs and talks of vulnerability and sadness. Memes show their view of life through posts called tours in which there is an episode of a call for help. Girls are being protagonists of our contemporary society fighting for a political agenda such as Ecology and Education. We can mention here Malala Yousafzai and Greta Thunberg. The YouTube channel, for example, brings the song of young people fighting for the environment in a movement against climate change. They sing: We need to wake up, to wise up, to build a better future and we need to start right now. The background song is Bella $\mathrm{Ciao}^{2}$ that was sung by the Italian resistance group against fascism and also against the Nazi's. Moreover, the current generation always communicates with other people using gifs, photos, and emojis. This means that the verbal mode (written or oral language) is not the most predominant in their communication with others, but is combined with different semiotic codes, as, for example, gestures, facial expressions, images, etc. This is evidence that their ways of meaning-making have changed, and they are always multimodal. 
All of this gives us a flavor of P-learners as they are called by Kalantzis and Cope (2012, p. 9) (P for participatory) who will be in our English classes hoping to learn a new language that is multifaceted with different semiotic modes which offers multiple modes of expressing meanings. Additionally, this new language is understood as a social semiotic action intertwined with different cultures, social communities, identities, and contexts. As such, today's students become frustrated "by an old-fashioned literacy curriculum that expects them to be passive recipients of knowledge that is deemed good for them" (p.10) - they want more than relevant content to be used in their lives, but real ones that depend on their active participation to collaborate with peers in meaningful projects with the tools of their time, follow their passions and share what they learnt with the world through the internet.

Prensky (2010, p.9) has been advocating learners' high potential for learning with digital tools which are becoming "smaller, better, and cheaper" throughout the years. Learners can put their digital potential in engaging with the cyclical processes of the multiliteracies pedagogy and turn into authors of their own work and share it with the world. Prensky's (2010) study has showed that today's learners do not want to be lectured but they want to create, using the tools of their time and to work with peers in collaboration. "They want an education that is not just relevant, but real" (Prensky, 2010, p. 2). Passions and interests are the key words in their learning outside of school. They want to be challenged and not exposed to traditional "telling" classes (Prensky, 2010, p.32).

In short, as Kalantzis and Cope (2012, p. 11) argue, today's students "have the capacity to source knowledge online or from other students or from experts, parents and community members" working "effectively in groups on collaborative projects, authoring knowledge to be jointly constructed or shared with peers". Today's youth "can innovate, take risks, negotiate diversity and navigate uncertainty" (p. 5) and are predisposed to learning anywhere and at any time using social media in their smartphones in ubiquitous ways.

\section{Methodology}

This is a qualitative interpretative study whose purpose is to examine the school textbook series, Time to Share (2018), published by the Brazilian Publishing House Saraiva, and approved by the 2020 PNLD committee for use in the public-education sector in Brazil. We are particularly interested in analyzing how the multiliteracies theory, its corresponding pedagogy, and students' active role are intertwined by the pedagogical design of this teaching material. We are also focused on particularly interested on creating new theoretical knowledge about our public-school textbooks in the hope of contributing to the area of materials productions within the field of Applied Linguistics.

The documentary research method refers to the analysis of documents that contain data researchers want to investigate. Documents can be defined as written texts that come from different sources, as, for example, educational government 
policies, diaries, school textbooks, census publications (Ahmed, 2010). As our research interest focuses on the investigation of a written document, an English public-school textbook, we selected this research method for our detailed analysis to interpret data and identify possible limitations. Other features that influenced our choice: readily available data that was relatively easy and not expensive to be gathered.

According to Ahmed (2010), handling documentary sources with the necessary scientific rigor involves quality control criteria related to authenticity, credibility, representativeness and meaning. As he explains,

[a]uthenticity refers to whether the evidence is genuine and from implacable source; credibility refers to whether the evidence is typical of its kind; representativeness refers to whether the documents consulted are representative of the totality of the relevant documents and meaning refers to whether the evidence is clear and comprehensible. [These criteria] should be seen as all interdependent and the researcher cannot adequately use one criterion to the exclusion of others (Ahmed, 2010, p. 3)

These four quality control criteria were appropriately considered in the process of handling our document for analysis based on our choice of this school textbook that has been evaluated and approved by the PNLD program. This indicates its educational quality and appropriateness for our context although it can be improved as our analysis will reveal. Our instruments of scrutiny will be the knowledge processes, experiencing, conceptualizing, analyzing critically and applying creatively of the multiliteracies pedagogy. We will also consider whether the pedagogical design implements the two "multis" in the learning activities and the role students play in interacting with them.

This school textbook, the written document under scrutiny, has eight units split into eight sections: The opening pages, Reading Comprehension, Focus on Vocabulary, Language in use, Listening Comprehension, Speaking, Writing, Selfevaluation. As acknowledged by the editor,

[t]he main objective of this series is to contribute to the whole education of students in the process of teaching English as an additional language in the final years of Secondary School. It addresses citizenship education and the development of multiliteracies for their understanding of the social, cultural, and linguistic diversities that characterize our contemporary society and influences on oral or written communication (Silvestre, Manual do Professor, 2018, p. VI)

The unit, Conscious Consumption, is the focus of our analysis, especially the two sections, Opening pages and Writing. Due to the scope of this article, we decided to center on these sections for a more detailed analysis although an overview of the series will also be given. The textbook was produced and organized collectively under the supervision of Alice Ribeiro Silvestre as it is mentioned on its cover. We selected this unit for analysis because the theme is of special 
importance in educating students to be more responsible towards the environment. As every attitude counts, our teens must stand up and become actively involved in eco-friendly behavior to guarantee environmental sustainability. Conscious Consumption is also a contemporary theme and awareness of its importance is an attitude to be developed in our classrooms. It is so relevant that " $[t]$ he United Nations has designated 5 June as World Environment Day to highlight that the protection and health of the environment is a major issue, which affects the wellbeing of peoples and economic development throughout the world" (UNESCO).

\section{Analysis}

An overall analysis of the whole series reveals that a balanced set of the knowledge processes, that is, the "how" of the multiliteracies pedagogy was implemented in all the eight units in cyclical ways, based on the "why" arguments coming from the NLG (1996). Our analysis also acknowledges the development of pedagogical actions related to the "what" of this pedagogy, that is, the two "multis" of the multiliteracies theory, multimodality, and multiple diversity. However, to accomplish its learning goals, Portuguese is excessively used throughout the units, not only in the instructions for the activities but also in the texts students must read to construct knowledge related to the well-chosen themes for the textbook. This is one of the main drawbacks of Time to Share. Although it should challenge the digital students it addresses, its learning activities do not always encourage them to take risks, to search for further information on their own, to indeed participate actively in their learning process, among other necessary competences for this century. Students are in fact controlled throughout and exposed to traditional "telling classes", a term coined by Prensky (2010, p.32).

Although the editor asserts in the teacher's manual that the pedagogical design actions are aimed at learners' active role in their interactions with the learning situations, they do not really consider that today's students demand more participation in what they do to learn. We noticed that there is an attempt to intentionally focus on learning activities oriented to learners' interests, cultural experiences, and identity but without real involvement that make them take real action to improve the place where they live and change their own attitudes for the betterment of others. The titles of the units, however, disclose concerns with themes of social relevance that reflect the variety of contextually significant issues around the world. Less concern is given to local issues related to the students' school, neighborhood, and personal lives. Some examples of such titles are Citizenship for all, Conscious consumption, Culture and arts, A healthy life.

The pedagogical design integrates a short section entitled "Para ler e navegar" (For reading and surfing) where URL addresses related to each unit concerning their topics, genres, grammar, and vocabulary are recommended for use outside of the classroom. Although this gives students opportunities to learn beyond the school environment, no guidelines are given regarding why, what, and how to use digital tools creatively for learning enhancement. Furthermore, the addresses 
are simply given to students who are used to playing video games and assuming a more involving attitude with what they do online. Follow up activities could have been proposed to build students' abilities in doing online research and developing critical thinking. Some could argue that public-school students do not have access to the Internet or free Wi-Fi connections for their assignments. However, one of our counterarguments is that some students do have access to the digital world, and they are being denied opportunities to learn English outside of the classroom and even work in collaboration with classmates to construct meaning.

Concerning the layout design, we noticed that the designers' choices were related to students' learning purposes and were set up for their successful achievements. However, it could be improved to include images that the target public can identify with. For example, the image on page 103 that was taken from an online free stock of photos has nothing to do with Brazilian sixth graders. The young lady in the photo is of European complexion; the family of four seems to be a group of foreigners and the closet does not contain clothes appropriate for their age. The sixth-grade students will most likely not create relationships with the scenario represented in this semiotic landscape. Consequently, the textbook's learning goal might not be reached as expected by the editor who created the activity.

\section{The opening pages}

The pedagogical design of the opening pages of all units draws on images that illustrate their corresponding themes that will be discussed in class to give students opportunities to relate what they already know to what is new for them. As such, to account for the process of experiencing old and new knowledge, the pedagogical design provides opportunities for students' discussions of the units' topics with the help of the English teacher who is encouraged (in the teacher's manual) to boost participation and encourage engagement so as that no-one feels left out of the discussions. In the sixth unit there are two images, one shows discarded clothing spread out to represent how harmful waste is to the environment ${ }^{3 .}$ The other shows a model standing on a pile of discarded clothing that was used to publicize the $6^{\text {th }}$ edition of the Eco Fashion Week (EFW) that takes place in the city of Vancouver in Canada ${ }^{4}$.

In addition to the images, right below the title, Conscious consumption, and the number 6 , for sixth unit, there is an excerpt that was probably translated into Portuguese by the textbook's editor from The glass magazine. It is also related to the Eco Fashion Week (EFW) and its founder. Students become aware that both images represent this event whose main purpose is "to promote the kind of sustainability necessary for [...] the long-term viability" of the fashion industry that is classified as one of the "most environmentally damaging [enterprise] in the world" (MIRSHAHI, 2013, online). Additional information is given about Myriam Laroche, the EFW founder. This is what is written in Portuguese on page 103: "Laroche founded the EFW and was its president from 2009 to 2017"; the launching took place in September 2010. During all this time of dedication to 
the well-being of the planet, "[h]er mission [was] to educate the industry and the public to be more responsible on how they buy, use and dispose of their apparel" (The University of Fashion, online). She promoted sustainable initiatives to raise awareness and to stimulate the growth and development of eco-conscious practices in the fashion/clothing industry.

The process of experiencing the new goes around discussions on the two images, the caption, Eco Fashion Week, 6'a edição. Vancouver, Canada. 2013, the excerpt from the online Glass Magazine translated into Portuguese and the additional information about Myriam Laroche, also in Portuguese, that clarify the purposes of this semiotic landscape on the opening pages. The primary objective of the unit is to promote critical reflections about excessive consumption. While discussing in class, students will have the opportunity to construct knowledge about the global fashion industry, but there is no mention of Brazilian industries or brands nor what types of industries are around the communities where the students live.

They probably know the important role fashion business plays in our society although they might not have yet realized how deeply it impacts the environment during the clothing production process by consuming large quantities of water, for example. This is new knowledge that might have been built by the sixth graders. Probably, with the teacher's moderation, students will mention the three R's of the environment, that are reuse, recycle and reduce, demonstrating what they already know. Based on what they learnt in interactions with the opening pages and classmates, they will probably highlight the lack of eco-friendly efforts by the fashion industry for sustainable attitudes that do not compromise international agreements for a cleaner planet. This is new knowledge that they might build to develop their awareness of some environmental issues, such as, climate change, global warming, water pollution, deforestation, and logging, for example.

Parallel to the experiencing the known and the new, other knowledge processes take place while students discuss, collaborate, give their position, and learn about the constructive power of conscious consumption. They create concepts related to the actions of the fashion industry that bring devastating negative effects on the environment. Most probably, they will come to an understanding that something must be done to raise awareness about the wellbeing of the environment. The process of critically analyzing the multimodal starting pages is enacted by the encouragement given by the English teacher aimed at discussions related to the harmful power of waste toward an eco-friendly planet. This encouragement is aimed at students' self-examination of their roles as citizens regarding the environment and the necessary care it deserves from us. Students are also challenged to critically analyze Myriam Laroche's initiatives and to explain what they could do for an ecofriendly environment in their school, in the neighborhood and in the place where they live. They could ask other teachers' help and for ideas of what to deal in the questions that would be prepared by them.

Although students are invited to participate in all the learning activities, our analysis reveals that the opportunities for advocating for a cause or social 
program are rare, except for the creation of a poster in the writing section. We will discuss this section later in this article. Regarding the use of digital tools, the textbook does not encourage students' participatory role in the creation of videos, podcasts, audio recordings and in the use of applications such as WhatsApp. Since students are very familiar with apps of all types, they could express their voice for a cleaner planet, for example.

\section{The writing section}

In the writing section, the pedagogical design gives students the chance to apply creatively what they had conceptualized, analyzed critically and learned about "conscious consumption" as well as about the genre ad (advertisement) in the sixth unit of Time to share. Students are encouraged to write an ad to publicize an event for the donation of clothing, shoes, and toys that will take place in their school under their leadership. This is a well-based writing activity on the claim that today's learners have to take greater responsibility for what they do to learn. Besides, "[ $\mathrm{t}]$ hey are the ones who actively participate, who solve problems, who innovate, who take calculated risks and who are creative" (Kalantzis \& Cope, 2012, p. 10).

Although this premise gives some theoretical support to the pedagogical design of the writing task oriented to be carried out in the learners' social contexts, all the instructions are given in Portuguese. This prevents students from constructing knowledge of the English language that they have to use in the process of creating the poster. Even though the pre-writing activity involves the pedagogical use of an YMCA ad publicizing donation of "warm clothing for the winter"s, it does not represent Brazilian winter situations if we consider the Northeast states of Brazil, for example. Moreover, it is most likely that our students have never heard of this organization, the YMCA. Nothing is discussed about weather differences within Brazil nor between our winter conditions and those of the country this ad comes from. However, some questions in English are asked about the YMCA ad aimed at students' understanding the social function and some of the multimodal characteristics of this genre. The answers may help them have a glimpse of what an ad is, how it is composed, why it is published, who gains or loses with its publication, for example. Students are not asked to go back to page 104 where they read an ad that publicizes the 2013 Eco Fashion Week and answered comprehension question about it. This could be a scaffolding artifact in the process of creating their ad. In short, the writing scenario is as follows.

What to write: A publicizing ad.

Purpose: Publicize a donation event of clothing, shoes, toys, etc.

For whom: The school community

Why to publicize the event: To receive donations for charity. Deliver the donations. 
For the process of writing the ad, only the main instruction is in English: "In pairs, create your own ad. Follow the steps below". All the steps are in Portuguese. Regretfully, this prevents students from having input in the language they are learning. The multimodal ensembles that are typical of the genre ad and some persuasive words or phrases that can be used are not even discussed with the students. However, some relevant information about this genre is given in the teacher' manual.

The pedagogical design purposefully considers current perspectives backing up the view of a "combined approach to writing" (Dias, 2020, p. 248). This view brings together the strengths of both process-oriented and genre-based approaches to support students in the challenging task of composing texts in different genres. The steps the students must follow as explained on pages 118 and 119 are in agreement with the writing stages represented in Figure 2.

Although there is some concern in supporting students in the writing activity, it is not appropriately materialized the way it should have been. For example, students could have been encouraged to read more ads and bring real ones to further discuss their characteristics with their classmates. Their favorite ads and the ones they evaluate as good exemplars could have been discussed in class. They could have been asked to search for slogans commonly used in ads and some vocabulary could also have been built in collaboration in the classroom. Based on the guidelines given on pages 118 and 119, it seems that the students worked together, planned their writing, learned the multimodal characteristics of ads, selected pictures to illustrate their ads, created drafts, wrote and rewrote versions, and edited their work. However, we cannot infer that the students have composed appropriate ads to meet their social roles.

Figure 2 - Stages in the Combined Approach to Writing

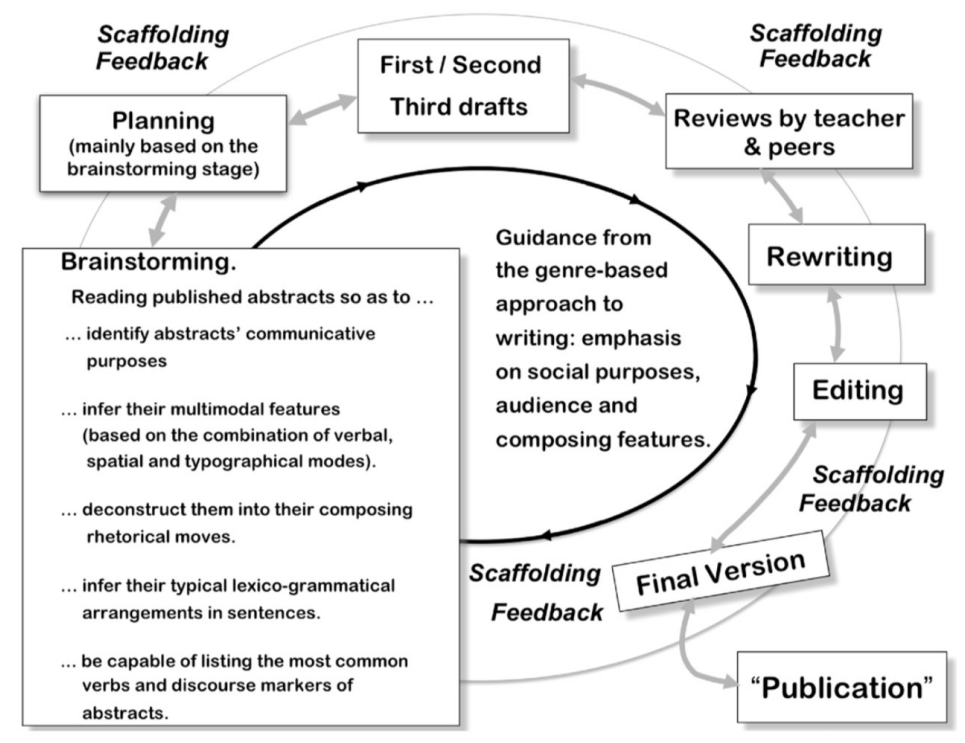

Source: Dias, 2020, p. 250 
The post-writing activity refers to the publication of the ads that were composed. Students were encouraged to publish them on the school walls where they could be read by other teachers and colleagues. In one of the guidelines, they are invited to use digital tools and the virtual environment as, for example, the school site, to publish their ads. This is a highly positive learning activity for today's learners since they become agents of what they must do to learn, besides being in an authentic situation of social relevance. Not only will English be learned in collaboration, but values of citizenry are also taking place. Social relevant learning activities will give our students opportunities to develop critical thinking and take actions for the betterment of themselves as citizens and others.

Overall, the Time to share series covers recent theoretical grounds related to literacies and their role in the process of learning English, especially in the teacher's manual. Genres of different social domains are its teaching instruments, and we could notice that the learning activities are related to them. The pedagogical moves of the multiliteracies pedagogy and the two "multis" are somewhat handled well in the Time to share series. The series, however, casts a shadow over the roles students should play during learning. The learning activities that are proposed rarely consider learners as active agents but expect them to be passive recipients of knowledge and compliant to what they are told to learn. In order to ensure that all students benefit from learning, the book activities have to be embedded in social and cultural contexts that make sense for them. Based on Kalantzis and Cope (2012, p. 10), the Time to share series should more often

encourage learners to be actively and purposefully engaged in their learning by setting them real intellectual and practical challenges [...] to make meaningful choices about what and how they learn in order to meet new, higher standards of performance and student wellbeing (Kalantzis \& Cope, 2012, p. 10)

\section{Suggestions for PNLD English teachers}

The school context in which English teachers work and the students who they are responsible for are the key points in our suggestions. Contextual clues go far beyond what is given about the Eco Fashion Week in unit 6. These clues must specifically refer to students' interests, identity, cultural experiences and willingness to get involved in the learning process. What is proposed on the opening pages has very little meaning to sixth graders who live in Brazil. Why is fashion among their interests? Who has heard of a fashion event that takes place in another country? Are events like this particular one a part of their cultural experiences? Do they take place where they live or in their states? Do the traditional festivals they attend include fashion styles and models parading on catwalks? The attempt to contextualize the theme related to Unit 6 may not have the desired effect on the target audience. 
In pedagogical situations for opening pages like the one in unit 6 , we think that some additional clues should be given before discussions in class. For example, where Canada is and what they know about it. Also, the geographic position based on a map or earth globe should be discussed, where this country is and how far it is from Brazil and where Vancouver is inside Canada. Students will rarely get interested in topics that are not part of their situated cultural experiences. Contextualizing is also a matter of purposes: why are they reading about this fashion week? Why do they need to construct knowledge about it?

In order to contextualize the theme "conscious consumption" for sixth graders, it would be a better idea to ask students to write or say it loud what consumption means for them. This would be a good opportunity to list words, phrases, and situations where consumption takes place using the English language. Their own English books and the others for other subjects, online dictionaries and translators could be of help. They could even be asked to draw what they understand of the concept. The visually oriented students of this age can deal with multimodal genres and events and representing ideas in semiotic landscapes, and this can engage them more deeply in what they are doing to learn.

Students could also ask their parents how much they spend per month and if there is excessive consumption of certain items by their families. They could discuss with their parents what to do for conscious consumption at home. Budget and consumption issues could also be discussed. Discussions could also occur with neighbors, relatives, older colleagues, and members of the school community, etc.

Furthermore, students could be encouraged to search for key words, such as, consumption, green consumerism, green planet, among others, in their own textbooks for the other subjects. They will certainly find written or visual information about topics related to these words and then interdisciplinary discussions can take place. Teachers should always encourage students do research in their own textbooks, including the ones for other subjects, in the library, in magazines, and on the Internet wherever possible. They have to get involved in the learning process and actively participate to solve problems, to sustain arguments, to do research using multiple sources of information, to create multimodal texts for different purposes and contexts, and to be aware of others' wellbeing.

It is needless to say that our students are ubiquitous participants of the digital world. Consequently, they should be stimulated not only to learn English in different applications, sites, and social media but also to search for information and construct knowledge and apply creatively what they have learned in innovative cultural artifacts and to attempt to arrive at acceptable solutions for problems our country is confronted with.

However, if students have limited access to the Internet, there are learning activities they can be involved with, such as, craftwork, paper games, simulated TV shows, offline clips, festivals of music, charges, comic strips, folk dances, etc. Active participation has to enter the learning scene to allow students to express themselves so their voices can be heard, appreciated, questioned, and shared. 
Above all, English teachers should always "[e]ngage learners as activeknowledge makers, [p] rovide [them] with opportunities to use the new media, [e]ncourage [them] to take more responsibility for their learning" if they take into account that "learning interactions continue out-of-hours and between home and school” (Kalantzis \& Cope, 2012, p. 12).

\section{Brief final remarks}

The main objective of our article is to encourage PNLD English teachers to reflect on recent theories related to teaching multiliteracies approaches and to prevailing arguments that highlight students' active role in the learning process. Our analysis of the Time to share series is our effort to show how theory and practice have been weaved in the book activities that are aimed on students' literacies development. All English textbooks, including the ones approved by the PNLD, need to be critically analyzed by teachers so they can identify their shortcomings and overcome them for the improvement of their pedagogical practices.

Our analysis of the Time to share series revealed that it follows the principles of recent theories in the development of the learning activities although there is an excessive use of the Portuguese language. Students are somewhat well encouraged to actively participate but more could be done in this sense. Further responsibility could be put upon the students in terms of interactions and research on the web. They are digital natives and their familiarity with this new world can make a difference in their involvement with learning English online for today and for the future. Their success depends on them, and they must be encouraged to learn by themselves. As Kalantzis and Cope (2012, p. 12) remind us, they can successfully

[r] esearch information, using multiple sources and media [a]nalize ideas from multiple perspectives $[w]$ ork in groups as collaborative knowledge-makers [t]ackle difficult questions and solve problems [c] ontinue their learning independently beyond [...] [the school walls] [c] ritically self-assess their own thinking and learning. (Kalantzis \& Cope, 2012, p. 12)

This reminder from Kalantzis and Cope (2012) should help us believe in our students' capacities and have them as our partners (Prensky, 2010) in our everyday learning journey and carry it out with great happiness.

Notes

1. We are thankful to Dr. Mary Kalantzis for her careful reading and insightful comments.

2. Bella ciao" ("Goodbye beautiful") is an Italian folk song that was adopted as an anthem of the anti-fascist resistance.

3. The image on the book only shows one the sides of the catwalk and can be seen at: https://edgexpo.com/2016/07/20/how-wasteful-are-we-the-fashion-industrysshocking-truth/. 
4. http://www.theglassmagazine.com/style-meets-sustainability-eco-fashion-week/.

5. https://pressat.co.uk/releases/ymca-launches-winter-warmer-campaign-forgiving-tuesday-d8e750bddea435f2561248ec2bd47c3c/.

\section{References}

Ahmed, J. U. (2010). Documentary Research Method: New Dimensions. Indus Journal of Management \& Social Sciences, 4(1), 1-14.

Brasil, MEC. (2020). Guia de livros didáticos: Língua estrangeira moderna - Espanhol - Inglês. Ensino Fundamental - Anos Finais.

Dias, R. (2015). Multimodalidade e multiletramento: novas identidades para os textos, novas formas de ensinar inglês. In K. A. da Silva \& J. Araújo. (Eds.). Letramentos, discursos midiáticos e identidades: novas perspectivas. Pontes, 305-325.

Dias, R. (2020). Writing abstracts in the university context: combining genre-based and process-oriented approaches. Trabalhos em Linguística Aplicada, 59(1), 240263. http://dx.doi.org/10.1590/010318136577815912020.

Dias, T. (2019.). Os imperfeitos. Folha de São Paulo. Retrieved from: htpps://tab.uol. com.br/edicao/geracao-z\#embed-1

Kalantzis, M. \& Cope, B. (2012). Literacies. Cambridge: Cambridge University Press.

Kalantzis, M. \& Cope, B. (2010). The teacher as designer: pedagogy in the new media age. E-Learning and Digital Media. 7(3), 200-222. https://doi.org/10.2304/ elea.2010.7.3.200.

Kress, G. (2010.) Multimodality: A Social Semiotic Approach to Contemporary Communication: London: Routledge.

Prensky, M. 2010. Teaching digital natives: partnering for real learning. Thousand Oaks, CA: Sage.

Silvestre, A. R. (2018). Time to share. 2ed. São Paulo: Saraiva.

The New London Group Manifest. (1996). A pedagogy of multiliteracies: Designing social futures. Harvard educational review, 66(1), 60-93.

Tornelli, J. R. A. \& Furlan, C. J. K. (2021). FELICE - Formação de professores e ensino de línguas para crianças. Retrieved from <http://dgp.cnpq.br/dgp/ espelhogrupo/7106943312930158>

UNESCO. (2021) World environment day. 2021 theme: Reimagine. Recreate. Restore. Retrieved from/https://en.unesco.org/commemorations/environmentday

Recebido em: 30/06/2021

Aceito em: 25/11/2021 